\title{
Knowledge of Middle East Respiratory Syndrome Coronavirus (MERS-CoV) and its Management: A Survey among Saudi People in Taif; Kingdom of Saudi Arabia
}

\author{
Abuabker Elbur ${ }^{1}$, Abdullah Alharthi $^{2}$, Abdulrahman Aljuaid ${ }^{2}$, Nawaf Hasan \\ Almalki ${ }^{2}$ \\ ${ }^{1}$ Department of Clinical Pharmacy, College of Pharmacy, Taif University, Kingdom of Saudi Arabia, \\ ${ }^{2}$ Pharm D student; College of Pharmacy; Taif University; KSA; Al-Haweiah, Taif, Kingdom of Saudi Arabia
}

\begin{abstract}
Background: Assessment of the public general knowledge on Middle East Respiratory Syndrome is crucial to the development of health policies for containment of the disease.

Objectives: To measure the level of public knowledge on Middle East Respiratory Syndrome and to identify its predicators.

Methods: A cross -sectional survey was conducted during June -October 2015, whereby adult ( $\geq 18$ years old) Saudi people residing in Taif Area were recruited. Convenience method of sampling was adopted. Data was collected by a structured questionnaire. Face-to-face interview method was used to collect the data. Data was processed and analyzed by the Statistical Package for Social Sciences (SPSS version 21). Logistic regression analysis was performed. P values $<0.05$ were considered statistically significant.

Results: A total of 377 participants was recruited (age range 18- 85 years). The majority was males and $65 \%$ were university graduates. Of all the interviewees $56 \%$ believed that the disease transmission can occurs through infected camel and bats. The fact that the disease has no specific treatment was known by $53.8 \%$ and $42.7 \%$ of them denied any role for traditional medicines in the prevention or treatment of the disease. Participants had satisfactory knowledge about the disease and its management were $216(57.3 \%)$. Significant predictors of satisfactory knowledge were age more than 40 years $\quad[\mathrm{OR}=0.4 ; 95 \% \mathrm{CI}(0.2-0.7) ; \mathrm{P}=0.001]$, university education $[\mathrm{OR}=1.6 ; 95 \% \mathrm{CI}(1.0-2.6) ; \mathrm{P}=0.042]$ and being employed in the medical field $[\mathrm{OR}=2.8$; 95\% CI (1.7-4.5); P < 0.001].

Conclusions: Despite the great effort done by the health authorities in the country to educate the people and to raise their awareness about the disease, there are gaps in public knowledge. Future planned educational interventions should focus on younger people and those with educational background below the university level.
\end{abstract}

\section{INTRODUCTION:}

The last two decades witnessed the emergence of several new viral respiratory tract diseases that threaten the global health [1]. Examples of these diseases are severe acute respiratory syndrome (SARS) and Middle East respiratory syndrome (MERS). MERSis a viral respiratory disease caused by a novel coronavirus (MERS-CoV) [2].The virus was first isolated in Saudi Arabia at 2012[3].The MERS-CoV is considered an epidemic in Saudi Arabia [4]. Occurrence of the disease and death are higher among men compared to women, and among people of age between 45-59 and >60 years had the highest mortality rate[4]. In Saudi since 2012 a total of 1413 cases was confirmed with the disease and 32 case with the disease without current symptoms; of them 610 died, 833 recovered, 2 patients under treatment [5].

Knowledge of the disease modes of transmission is important for developing effective control measures. The transmission of MERSis defined as sporadic, between family members, often occur in health care settings, and requiring close and prolonged contact [6].The disease is often a lower respiratory tract one, with the following signs and symptoms: Fever; cough; breathing difficulties; pneumonia, which can progress to acute respiratory distress syndrome; multiorgan failure and death among more than a third of the infected patients[7]. Although, without definitive scientific evidence, the use of some antiviral drugs alone or combined with corticosteroids may improve the outcome of therapy among some patients; no specific therapeutic treatment or vaccine available for the disease.

Health authorities in Saudi did substantial efforts in order to control the disease through various measures. Public education is considered as one of the most important measures that can help in the control of infectious diseases. Few studies were conducted in Saudi among the public and health care workers to assess knowledge about the disease and its management [9-11].Assessment of the public general knowledge on MERS is crucial for developing health policy for the containment of the disease. Therefore, this study was conducted 
Knowledge of Middle East Respiratory Syndrome Coronavirus (MERS-CoV)

to achieve the following objectives: To measure the level of public knowledge on MERS and to identify sociodemographic variables associated with satisfactory level of knowledge if any.

\section{METHODS:}

Study design and setting:

A cross -sectional survey was conducted during June -October 2015 in Taif City, Kingdom of Saudi Arabia.

Inclusion and Exclusion criteria:

Adult ( $\geq 18$ years old) Saudi people residing in the city were included. The exclusion criteria were: refusal to participate and people who were mentally incapable to communicate. The objectives of the study were stated clearly for the participants before commencement of the interview process.

\section{Sample and sampling technique:}

A convenience method of sampling was adopted and a total of 377 agreed to participate and included in the study.

\section{Data collection:}

Data was collected by mean of a structure questionnaire. Face-to-face interview method was used to collect the data by semi-final year Pharm-D students. The data was collected in public places in the city (Malls, supermarkets, parks, schools, and restaurants). The average time to conduct the interview was estimated to be 10 minutes. The questionnaire items were developed based on the educational material published by Saudi Ministry of Health [5]. The questionnaire was tested with a group of 10 people to ensure applicability and estimate the time frame needed to complete it. Minor suggestions were observed and adopted in the final version. The questionnaire was composed of six parts to collect data on:-

1-Participants demographic characteristics: gender, age in year, residence, educational level, type of current job, and history of contracting the disease or infection of one of the family members or friends and relatives.

2-Knowledge of disease etiology through one question( is the disease caused by bacteria, virus or both of them)

3 -Knowledge of disease symptoms, through six questions, whereby common six signs and symptoms were listed.

4-Knowledge of modes of transmission of the disease, through four questions to measure the public knowledge on human-to-human transmission or animal to human transmission.

5-Knowledge of preventive measures, whereby seven preventive measures were selected and ranged from global adherence to hygiene tospecific like washing hands with water and soap.

6-Knowledge about treatment and availability of vaccines for prevention through nine questions.

Evaluation of total knowledge: Responses to the last five parts of the questionnaire were recorded as "Yes", " No" and "Don't know". The participant was given a score $=1$ if he/she answered the question correctly and zero score if he/she fail to identify the correct answer or he/she did not know the correct answer to end up with a total ranging from 0-27. Finally, the participant was classified as having satisfactory knowledge about the disease and its treatment if he/she scored $\geq 22$ points and not having satisfactory knowledge if the score was below this cutoff point.

\section{Data analysis:}

Data was processed by the Statistical Package for Social Sciences (SPSS) version 20. Descriptive statistics were used to describe all variables. Mean and standard deviation was used to identify mean scores for different studied domains. The Chi-square test was used to test the difference in proportions between medical field employees' knowledge on disease treatment and other respondents . Logistic regression analysis was performedto determine the most significant demographic variables (independent) associated with satisfactory knowledge of the disease and its treatment (dependent).Crude logistic regression analysis was performed as an initial step of qualifying covariates to be included in multivariate logistic regression analysis. $P$ value $<0.05$ was considered statistically significant.

\section{ETHICAL APPROVAL:}

Ethical approval for the conduction of the research was obtained from the Pharmacy Practice Research Unit (PPRU), College of Pharmacy, Taif University, Saudi Arabia.

\section{RESULTS:}

\section{Respondents' demographic characteristics:}

A total of 377 participants was recruited (age range 18- 85 years). The majority were males and $65 \%$ had university education. Employees in the medical field were 115(30.2\%). Table (1)showed participants' demographics. 


\section{Knowledge of the causative agent:}

The majority of the participants $276(73.2 \%)$ knew that the disease is caused by a virus. However, $57(15.1 \%)$ incorrectly had the belief that both bacteria and virus cause the disease, 34(9\%) did not know the causative agent and $10(2.7 \%)$ believed the disease is a bacterial one.

\section{Knowledge of disease transmission:}

Of all the interviewees $333(88.3)$ knew that the disease is transmitted through droplets produced during coughing or sneezing and 211(56\%) believed that the disease transmission can occur through infected camel

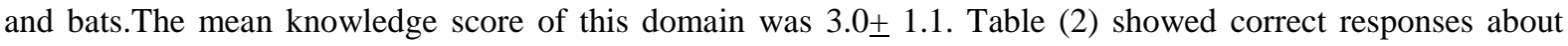
disease transmission, symptoms and preventive measures.

\section{Knowledge of symptoms of the disease:}

The majority of respondents showed high level of knowledge about the respiratory symptoms of the disease and 231(61.3\%) reported that diarrhea can be one of the symptoms, table (2). The mean knowledge score of this domain was $4.8 \pm 1.6$.

\section{Knowledge of disease prevention measures:}

The majority of interviewees had good knowledge about most of the preventive measures that can help in limiting the disease transmission, table (2). The mean knowledge score of this domain was $6.2 \pm 1.2$.

\section{Knowledge on disease treatment:}

The fact that the disease has no specific treatment was known by $203(53.8 \%)$ and 161(42.7\%) of them denied any role for traditional medicines in the treatment of the disease. The mean knowledge score of this domain was $6.4 \pm 1.9$.

\section{Total knowledge and its predictors:}

Participants had satisfactory knowledge about the disease and its management were 216( 57.3\%). Significant predictors of satisfactory knowledge were age more than 40 years $\quad[\mathrm{OR}=0.4 ; 95 \% \mathrm{CI}(0.2-0.7) ; \mathrm{P}=$ $0.001]$, university education [OR=1.6;95\% CI (1.0-2.6); $\mathrm{P}=0.042]$ and being employed in the medical field $[\mathrm{OR}=2.8 ; 95 \% \mathrm{CI}(1.7-4.5) ; \mathrm{P}<0.001]$. Table (4) showed the difference in knowledge between medical field employees and other respondents and Table (5) showed the determinants of satisfactory knowledge about the disease and its treatment.

\section{DISCUSSION}

Few studies were conducted in Saudi among the public and health care workers to assess their knowledgeon The Middle East Respiratory Syndrome and its management. To the best of our knowledge this study is the first of its type in the Western part of the country. The study questionnaire was developed based on the educational messages published on the website of the Ministry of Health. These messages are inclusive as it covers modes of transmission of disease, clinical symptoms, preventive measures and treatment domains. So, the participants' knowledge was assess a cross all the mentioned domains. This information give our study more strength, compared to other studies.

The distribution of the demographic variables of the respondents showed a high percentage of participation of males, highly educated and town dwellers. This may be justified by the facts that females due to cultural norms in the country have a little opportunity to participate in such public survey, specifically if the data collectors are males. The highly educated people, most of them were living in the city, accept to participate in such studies more than low educated ones.

Nearly more than one quarter of the interviewees did not exactly know that the causative agent of the disease is a virus. Knowledge of the etiological agent is considered as the first step of patient education. Once the people know the agent they are most probably understand how the disease is transmitted and what are the preventive measures that limit its distribution.

Nearly $57 \%$ of the respondents were classified as knowledgeable about the disease and its management. We applied a stringent cutoff point $(\geq 80 \%)$ to classify that the participant had satisfactory knowledge about the disease and its treatment. This is because we believed that the educational messages published by the health authorities are direct and simplified. Another previous study in the capital of Saudi found that the knowledge of MERS among public was suboptimal and knowledge was the significant predictor of both the level of concern and precaution [9]. 
Despite the fact that Medical field employees recruited in this survey were found to be more knowledgeable compared to other participants, they had gaps in knowledge in some items. Comparatively, other researchers in Al Qassim Area found that healthcare workers had good knowledge and attitude towards MERS [10]. However, in another study among healthcare workers in Makkah the authors reported knowledge gap and negative attitudes toward the disease [11].

Although research has revealed that camel could be the main source of MERS [12], 56\% of the respondents linked disease transmission to this animal. In the above mentioned study [10], 44\% of the participants had lack of knowledge about the source of MERS-CoV. Public and healthcare workers should be clearly educated about this important information.

The most identified gaps in knowledge among interviewees were on disease treatment domain. No difference in the belief that traditional medicines like herb can be used as remedy for the disease between healthcare workers and others. The use of traditional and herbal medicines is very important component of Saudi nation folklore.

The same identified gaps in the treatment domain (no specific treatment for the disease and no vaccine can prevent from the disease ) were reported in electronically conducted national survey [13]. Future educational messages to raise the awareness of the public should focus on these items as it may motivate them to adhere to strictly to the preventive measures and help in the containment of the disease.

Significantly higher education and older age (> 40 years) were identified as predicators of good knowledge. Definitely higher level of education helps in understanding the educational messages. In addition, highly educated people have the capability to obtain information about the disease from different sources, which cannot be readily accessible to low educated ones. Likewise the same variables were associated with more knowledge in the above mentioned national survey [13].Future interventions should target the youngers and individuals with low educational background.

Few studies were conducted outside Saudi to assess the knowledge about MERS. In this respect, researchers assessed the knowledge of people who were planning to travel to Saudi to visit the Holy the areas. These studies revealed poor knowledge about the disease [14], [15].So, substantial and continuous effort is needed from the health authorities to raise the level of awareness of Hajj pilgrims and other visitors to the Holy areas with the disease.

The study was conducted in one city in the country this limit the generalizability of the study to all population in the country. Future research should recruit people from different parts of the country in order to better assess the public knowledge about the disease and its management. Stratified sampling is also required in order to measure exactly the knowledge of each subgroup of the society.

\section{CONCLUSIONS:}

Despite the great effort done by the health authorities in the country to educate the people and to raise their awareness with the disease, still there are gaps in knowledge. Participants of aged $>40$ years, had university education and healthcare workers had better knowledge about the disease and its management.

\section{RECOMMENDATIONS:}

Future educational interventions to raise the public awareness with the disease should focus on younger people, with educational background below the university level. The educational messages should be designed in a more simplified format and delivered through the primary health care facilities, which are well-distributed in the country.

\section{REFERENCES}

[1] Al-Tawfiq JA, Zumla A, Gautret P, Gray GC, Hui DS , Al-Rabeeah AA, Ziad A Memish ZA, Surveillance for emerging respiratory viruses The Lancet Infectious Diseases .2014; 14 : 992 - 1000.

[2] WHO. Middle East respiratory syndrome coronavirus (MERS-CoV). Fact sheet N401 June 2015. http://www.who.int/mediacentre/factsheets/mers-cov/en/. Last accessed 24.Feb 2016.

[3] Zaki AM, van Boheemen S, Bestebroer TM, Osterhaus AD, Fouchier RA. Isolation of a novel coronavirus from a man with pneumonia in SaudiArabia. N Engl J Med.2012; 367:1814-1820.

[4] Alghamdi IG, Hussain II, Almalki SS, Alghamdi MS, Alghamdi MM, El-Sheemy MA. The pattern of Middle East respiratory syndrome coronavirus in Saudi Arabia: a descriptive epidemiological analysis of data from the Saudi Ministry of Health. Int J Gen Med. 2014; 7: 417-423.

[5] Saudi Ministry of Health Command and Control Center. http://www.moh.gov.sa/en/CCC/PressReleases/Pages/default.aspx. Last accessed 24.Feb 2016.

[6] Mackay IM, Arden KE. MERS coronavirus: diagnostics, epidemiology and transmission. Virol J. 2015; 22;12:222. doi: 10.1186/s12985-015-0439-5.

[7] Mackay IM, Arden KE.Middle East respiratory syndrome: An emerging coronavirus infection tracked by the crowd. Virus Res.2015; 202:60-88.. 
Knowledge of Middle East Respiratory Syndrome Coronavirus (MERS-CoV)

[8] Momattin H, Mohammed K, Zumla A, Memish ZA, Al-TawfiqJA. Therapeutic options for Middle East respiratory syndrome coronavirus (MERS-CoV)--possible lessons from a systematic review of SARSCoVtherapy.Int J Infect Dis. 2013 ; 17:e792-8.

[9] Almutairi KM, et al. Awareness, attitudes, and practices related to Coronavirus pandemic among public in Saudi Arabia. Family \& Community Health. 2015.38 (4 ) 332-340.

[10] Khan MU, Shah S, Ahmad A, Fatokun O. Knowledge and attitude of healthcare workers about middle east respiratory syndrome in multispecialty hospitals of Qassim, Saudi Arabia. BMC Public Health. 2014;14:1281. doi:10.1186/1471-2458-14-1281.

[11] Nour et al. knowledge, attitude and practices of healthcare providers towards MERS - CoV infection at Makkah hospitals, KSA. International Research Journal of Medicine and Medcial Sciences 2015. 3:103112.

[12] .Hawkes N. Camels could be the source of MERS coronavirus, research finds. BMJ. 2013;347:f5052. doi: 10.1136/bmj.f5052.

[13] Al-Mohrej OA, et al . Is the Saudi public aware of Middle East respiratory syndrome? J Infec Public Health(2015) DOI: http://dx.doi.org/10.1016/j.jiph.2015.10.003.

[14] Sahin MK, Aker S, KaynarTuncel E. Knowledge, attitudes and practices concerning Middle East respiratory syndrome among Umrah and Hajj pilgrims in Samsun, Turkey, 2015. Euro Surveill. 2015;20(38):pii=30023. DOI: http://dx.doi.org/10.2807/1560-7917.ES.2015.20.38.30023.

[15] Tashani M, Alfelali M, Barasheed O, Fatema FN, Alqahtani A, Rashid H, Booy R. AustralianHajj pilgrims' knowledge about MERS-CoV and otherrespiratoryinfections. Virol Sin. 2014;29:318-20.

Table (1) Basic and demographic characteristics

\begin{tabular}{|c|c|c|}
\hline Background characteristic & Frequency & Percentage \\
\hline $\begin{array}{l}\text { Gender } \\
\text { Male } \\
\text { Female }\end{array}$ & $\begin{array}{l}291 \\
86\end{array}$ & $\begin{array}{l}77.2 \\
22.3\end{array}$ \\
\hline $\begin{array}{l}\text { Age in year } \\
\leq 40 \\
>40\end{array}$ & $\begin{array}{l}276 \\
101\end{array}$ & $\begin{array}{l}73.2 \\
26.8\end{array}$ \\
\hline $\begin{array}{l}\text { Residence } \\
\text { Town } \\
\text { Outside town }\end{array}$ & $\begin{array}{l}350 \\
027 \\
\end{array}$ & $\begin{array}{l}92.8 \\
07.2 \\
\end{array}$ \\
\hline $\begin{array}{l}\text { Educational Level } \\
\text { University \& above } \\
\text { Below university }\end{array}$ & $\begin{array}{l}245 \\
132\end{array}$ & $\begin{array}{l}65.0 \\
35.0\end{array}$ \\
\hline $\begin{array}{l}\text { Occupation } \\
\text { Medical field } \\
\text { Outside the medical field }\end{array}$ & $\begin{array}{l}115 \\
262 \\
\end{array}$ & $\begin{array}{l}30.5 \\
69.5 \\
\end{array}$ \\
\hline $\begin{array}{l}\text { Marital status } \\
\text { Married } \\
\text { Single } \\
\end{array}$ & $\begin{array}{l}189 \\
188 \\
\end{array}$ & $\begin{array}{l}50.1 \\
49.9 \\
\end{array}$ \\
\hline $\begin{array}{l}\text { Did you or one of your family or relatives or } \\
\text { friends had MERS } \\
\text { Yes } \\
\text { No }\end{array}$ & $\begin{array}{l}026 \\
351\end{array}$ & $\begin{array}{l}06.9 \\
93.1\end{array}$ \\
\hline Total & 377 & 100 \\
\hline
\end{tabular}

Table (2): Correct responses of the public on the disease transmission, symptoms and prevention measures

\begin{tabular}{|l|l|}
\hline Item & $\begin{array}{l}\text { Frequency (\%) } \\
\text { (N=377) }\end{array}$ \\
\hline $\begin{array}{l}\text { Mode of transmission } \\
\text { Direct transmission through droplets produced during coughing or sneezing } \\
\text { Touching surfaces and devices contaminated by the virus }\end{array}$ & $333(88.3)$ \\
$\begin{array}{l}\text { Direct contact with infected patients } \\
\text { Transmission through infected camel and bats }\end{array}$ & $284(75.3)$ \\
& $211(87.8)$ \\
\hline
\end{tabular}




\begin{tabular}{|l|l|}
\hline Symptoms of the disease & \\
Congestion in the nose and throat & $308(81.7)$ \\
Cough & $319(84.6)$ \\
Fever & $339(89.9)$ \\
Shortness of breath & $318(84.4)$ \\
Diarrhea & $231(61.3)$ \\
severe pneumonia "in advanced case" & $296(78.5)$ \\
\hline Prevention measures & $361(95.8)$ \\
Wash hands with water and soap & $328(87.0)$ \\
Avoid touching the eyes, nose and mouth with hands & $342(90.7)$ \\
Avoid contacting with infected people & $346(91.8)$ \\
Use handkerchief when coughing or sneezing & $258(68.4)$ \\
Put on face-masks only if you are sick or visiting sick patients & $358(95.0)$ \\
Adhere to hygiene & $338(89.7)$ \\
Pay attention to other health habits &
\end{tabular}

Table (3) correct responses about the disease treatment

\begin{tabular}{|l|l|}
\hline Item & $\%$ Correct response \\
\hline Take antipyretic and painkillers medications & $298(79.0)$ \\
\hline Drink a lot of fluids & $308(81.7)$ \\
\hline A review of the health facility if necessary & $349(92.6)$ \\
\hline $\begin{array}{l}\text { Elderly patients, health practitioners, people in contact with camels and } \\
\text { people of chronic diseases or diseases affecting the immune system, } \\
\text { have to review the health facility when feeling symptoms of the } \\
\text { disease. }\end{array}$ & $319(84.6)$ \\
\hline There is no specific treatment for MERS & \\
\hline MERS disease can be cured & $203(53.8)$ \\
\hline MERS can leads to death & $293(77.7)$ \\
\hline MERS can be treated by traditional medicines & $333(88.3)$ \\
\hline No vaccine for the prevention of MERS & $161(42.7)$ \\
\hline
\end{tabular}

Table (4): Comparison of respondents' knowledge on disease treatment domain by occupation type

\begin{tabular}{|l|l|l|l|}
\hline \multirow{2}{*}{ Item } & \multicolumn{2}{l|}{ \% Correct response } & \multirow{2}{*}{ P value } \\
\cline { 2 - 3 } & $\begin{array}{l}\text { Medical } \\
\text { field (n= } \\
\mathbf{1 1 5})\end{array}$ & $\begin{array}{l}\text { Outside the } \\
\text { medical field } \\
(\mathbf{n = 2 6 2})\end{array}$ & \\
\hline Take antipyretic and painkillers medications & 87.0 & 75.6 & 0.008 \\
\hline Drink a lot of fluids & 92.2 & 77.1 & $<0.001$ \\
\hline A review of the health facility if necessary & 94.8 & 91.6 & 0.051 \\
\hline There is no specific treatment for MERS & 62.6 & 50.0 & 0.016 \\
\hline MERS disease can be cured & 84.3 & 74.8 & 0.026 \\
\hline MERS can leads to death & 89.6 & 87.8 & 0.278 \\
\hline MERS can be treated by traditional medicines & 40.0 & 43.9 & 0.278 \\
\hline No vaccine for the prevention of MERS & 50.4 & 35.5 & 0.005 \\
\hline
\end{tabular}

Table (5):Determinants of satisfactory Knowledge

\begin{tabular}{|c|c|c|c|c|c|c|}
\hline Covariates & $\begin{array}{c}\% \text { with } \\
\text { satisfact } \\
\text { ory } \\
\text { knowle } \\
\text { dge } \\
\end{array}$ & $\begin{array}{l}(\mathbf{n}= \\
377)\end{array}$ & $\begin{array}{c}\text { Univariable } \\
\text { analysis } \\
\text { crude OR( } \\
95 \% \mathrm{CL})\end{array}$ & $\begin{array}{l}\mathrm{P} \\
\text { value }\end{array}$ & $\begin{array}{l}\text { Multivaria } \\
\text { ble analysis } \\
\text { crude OR( } \\
95 \% \text { CL) }\end{array}$ & $\begin{array}{l}\mathrm{P} \\
\text { value }\end{array}$ \\
\hline $\begin{array}{l}\text { Gender } \\
\text { Male } \\
\text { Female }\end{array}$ & $\begin{array}{l}58.1 \\
54.7\end{array}$ & $\begin{array}{l}291 \\
086\end{array}$ & $1.1(0.7-1.9)$ & 0.573 & & \\
\hline
\end{tabular}


Knowledge of Middle East Respiratory Syndrome Coronavirus (MERS-CoV)

\begin{tabular}{|c|c|c|c|c|c|c|}
\hline $\begin{array}{l}\text { Age group in } \\
\text { year } \\
\leq 40 \\
>40\end{array}$ & $\begin{array}{l}51.8 \\
72.3\end{array}$ & $\begin{array}{l}276 \\
101\end{array}$ & $0.4(0.3-0.7)$ & $\begin{array}{l}<0.00 \\
1\end{array}$ & $0.4(0.2-0.7)$ & $\begin{array}{l}<0.00 \\
1\end{array}$ \\
\hline $\begin{array}{l}\text { Residence } \\
\text { Urban } \\
\text { Rural }\end{array}$ & $\begin{array}{l}58.0 \\
48.1\end{array}$ & $\begin{array}{l}350 \\
027\end{array}$ & $1.5(0.7-3.3)$ & 0.321 & & \\
\hline $\begin{array}{l}\text { Educational } \\
\text { level } \\
\text { University\& } \\
\text { above } \\
\text { Below } \\
\text { university }\end{array}$ & $\begin{array}{l}60.4 \\
51.5\end{array}$ & $\begin{array}{l}245 \\
132\end{array}$ & $1.4(0.9-2.2)$ & 0.037 & $1.6(1.0-2.6)$ & 0.042 \\
\hline $\begin{array}{l}\text { Marital status } \\
\text { Married } \\
\text { Single }\end{array}$ & $\begin{array}{l}61.9 \\
52.7\end{array}$ & $\begin{array}{l}189 \\
188\end{array}$ & $1.5(1.0-2.2)$ & 0.070 & & \\
\hline $\begin{array}{l}\text { Occupation } \\
\text { Medical Field } \\
\text { Outside the } \\
\text { medical field }\end{array}$ & $\begin{array}{l}74.8 \\
49.6\end{array}$ & $\begin{array}{l}115 \\
262\end{array}$ & $3.0(1.8-4.9)$ & $\begin{array}{l}<0.00 \\
1\end{array}$ & $2.8(1.7-4.5)$ & $\begin{array}{l}< \\
0.001\end{array}$ \\
\hline
\end{tabular}

